\title{
Bioedusiana
}

http://jurnal.unsil.ac.id/index.php/bioed

DOI: https://doi.org/10.37058/bioed.v6i2.2772

\section{Pengalaman Praktik Mengajar Calon Guru Biologi di Masa Pandemi COVID-19}

\section{Teaching Practice Experience of Biology Teacher Candidates during COVID-19 Pandemic}

\author{
Dios Sarkity ${ }^{1 *}$, Adam Fernando ${ }^{2}$ \\ 1,2 Program Studi Pendidikan Biologi Fakultas Keguruan dan Ilmu Pendidikan Universitas Maritim Raja \\ Ali Haji, Pulau Dompak, Tanjungpinang 29115.
}

\begin{abstract}
Abstrak
Sejak akhir Desember 2019 dunia digemparkan dengan penemuan virus baru yang dinamakan COVID-19. Virus ini dalam waktu singkat menyebar ke berbagai negara termasuk Indonesia. Untuk menekan laju penyebaran COVID-19, upaya pencegahan dilakukan diberbagai sektor termasuk sektor pendidikan. Upaya pencegahan dilakukan dengan mengalihkan sistem pembelajaran tatap muka menjadi pembelajaran dalam jaringan (daring). Dalam pelaksanaannya, pembelajaran daring masih mengalami berbagai kendala baik yang dirasakan guru maupun siswa. Pandemi COVID19 juga berdampak pada mahasiswa yang akan melaksanakan kegiatan praktik mengajar di Sekolah dimana praktikkan harus beradaptasi dengan sistem pembelajaran daring yang merupakan bentuk praktik pembelajaran yang bukan hanya dirasakan baru bagi praktikkan tetapi juga bagi guru yang telah lama mengajar. Penelitian ini merupakan penelitian survei berbentuk deskriptif yang melibatkan 51 responden yang merupakan mahasiswa Pendidikan Biologi FKIP Universitas Maritim Raja Ali Haji yang melaksanakan praktik mengajar di masa Pandemi. Penelitian bertujuan untuk menggali pengalaman responden tentang pelaksanaan pembelajaran daring yang dilaksanakan dari segi bentuk pembelajaran, persiapan pembelajaran, pelaksanaan pembelajaran dan evaluasi, platform online yang digunakan dalam pembelajaran, serta kendala dan manfaat yang dirasakan dari pembelajaran daring. Hasil penelitian menunjukkan bahwa responden masih beradaptasi dalam melaksanakan pembelajaran daring sehingga mengalami kesulitan dalam mempersiapkan dan pelaksanaan pembelajaran. Permasalahan yang dialami berkaitan dengan perangkat pembelajaran daring, koneksi internet dan kuota internet. Responden juga mengalami kesulitan dalam melakukan evaluasi karena terbatasnya akses pengawasan terhadap siswa. Namun demikian, pembelajaran daring juga memberikan manfaat dalam hal peningkatan penguasaan teknologi.
\end{abstract}

Kata kunci: Pembelajaran Daring; Pandemi; COVID-19; Platform Online

\begin{abstract}
Since the end of December 2019, the world had been shocked by the discovery of a new virus called COVID-19. This virus in a short time spread to many countries including Indonesia. To reduce the rate of spread of COVID-19, prevention efforts were made in various sectors including the education sector. Prevention was carried out by switching the face-to-face learning system into online learning. In its implementation, online learning still experienced various obstacles, both for teachers and students. The COVID-19 pandemic also had an impact on students who would carry out teaching practice activities in schools where practitioners had to adapt to the online learning system which was a form of learning practice that was not only felt strange for practitioners but also for teachers who had been teaching for a long time. This research was a descriptive survey research involving 51 respondents that were students of Biology Education of FKIP Universitas Maritim Raja Ali Haji who carried out teaching practices during the Pandemic. The research aimed to explore respondents' experiences regarding the implementation of online learning which was carried out in terms of the form of learning, learning preparation and implementation of learning and evaluation, the online platform used in learning, and the perceived constraints and benefits of online learning. The results showed that the respondents were still adapting in implementing online learning so that they had difficulty in preparing and implementing the learning. The problems experienced were related to online learning devices, internet connections and internet quotas. Respondents also experienced difficulties in conducting evaluations due to limited access to supervision of students. Online learning also provides benefits in terms of increasing mastery of technology.
\end{abstract}

Keywords: Online Learning; Pandemic; COVID-19; Online Platform

Article History

Received: March $1^{\text {st }}, 2021$; Accepted: November 19 ${ }^{\text {th }}, 2021$; Published: December $31^{\text {st }}, 2021$

Corresponding Author*

Dios Sarkity, Universitas Maritim Raja Ali Haji,E-mail: diossarkity@umrah.ac.id

(C) 2021 Bioedusiana. This is an open access article under the CC BY-SA 4.0 license

(https://creativecommons.org/licenses/by-sa/4.0/) 


\section{PENDAHULUAN}

Pada akhir 2019, dunia digemparkan dengan penemuan virus baru. Virus baru ini dinamakan COVID-19 (Corona Virus Disease 19) yang pertama kali ditemukan di Kota Wuhan, Cina pada Desember 2019 (Phan, 2020; Wang et al., 2020; Zhu et al., 2020). Terhitung sejak akhir Desember 2019, COVID-19 terus menyebar ke seluruh dunia (Shereen et al., 2020) sehingga WHO menetapkan COVID-19 sebagai pandemi (Cucinotta \& Vanelli, 2020; LloydSherlock et al., 2020; Mahase, 2020; Sohrabi et al., 2020).

Untuk menekan penyebaran COVID-19, berbagai upaya dilakukan di berbagai sektor, termasuk sektor Pendidikan. Beberapa negara menutup institusi pendidikan sebagai upaya pencegahan (UNESCO, 2019) termasuk Indonesia dengan dikeluarkannya Surat Edaran Mendikbud Nomor 3 Tahun 2020 tentang Pencegahan COVID-19 pada Satuan Pendidikan (Kemdikbud, 2020a), dan Nomor 36962/MPK.A/HK/2020 tentang Pembelajaran secara Daring dan Bekerja dari Rumah dalam Rangka Pencegahan Penyebaran COVID-19 (Kemdikbud, 2020b). Upaya pencegahan dan pengendalian dilakukan untuk menekan laju penyebaran COVID-19 (Chang et al., 2020; Wang et al., 2020).

Dalam rangka menekan laju penularan COVID-19, sistem pembelajaran dialihkan dari tatap muka menjadi pembelajaran dalam jaringan (daring). Pembelajaran daring merupakan suatu hal yang baru bagi banyak praktisi pendidikan (Annur, 2020; Astini, 2020). Dengan karakter siswa yang cenderung lebih menyukai pembelajaran tatap muka yang memudahkan interaksi antara siswa dan siswa maupun siswa dan guru (Meulenbroeks, 2020), maka seorang guru harus senantiasa memotivasi siswa untuk belajar (Rahiem, 2021) agar tidak menurunnya antusias siswa untuk mengikuti pembelajaran meskipun dengan sistem pembelajaran daring (Cahyani et al., 2020). Keberhasilan pelaksanaan pembelajaran daring diantaranya didukung oleh kemampuan guru dalam mengelola pembelajaran (Fernando, 2018; Glava \& Glava, 2012; Napitupulu, 2020) serta kemampuan guru dan siswa dalam menggunakan teknologi (Asmuni, 2020; Azubuike et al., 2020; Salsabila et al., 2020; Sudrajat, 2020). Keberhasilan pembelajaran daring juga tidak terlepas dari keterlibatan aktif siswa di dalam pembelajaran (Dahalan et al., 2012; Ishtaiwa \& Aburezeq, 2015; Sun, 2014).

Dalam pelaksanaannya, pembelajaran daring dilaksanakan dengan memanfaatkan berbagai platform online. Platform online yang paling banyak digunakan adalah WhatsApp dan Google Classroom (Bacher-Hicks et al., 2021; Gunawan et al., 2020; Hindrasti \& Sabekti, 2020; Mishra et al., 2020; Ningsih, 2020; Oktawirawan, 2020; Zhafira et al., 2020). Platform video conference seperti Zoom dan Google Meet juga efektif digunakan dalam pembelajaran daring karena memungkinkan terjadinya interaksi secara live streaming (Cuaca Dharma et al., 2017; Elzainy et al., 2020; Lapitan et al., 2021; Muthuprasad et al., 2021; Puspitorini, 2020; Rustaman, 2020). Selain pembelajaran live streaming, pembelajaran asynchronous dengan memanfaatkan platform 
online seperti YouTube dengan mengunggah video pembelajaran yang telah dibuat juga efektif dilaksanakan pada pembelajaran daring (Kim et al., 2020; Lapitan et al., 2021; Muthuprasad et al., 2021). Berbagai platform online lain juga banyak digunakan bergantung pada fungsi dan kebutuhan pengguna (Andel et al., 2020; Bulan \& Zainiyati, 2020; Ishtaiwa \& Aburezeq, 2015).

Perubahan sistem pembelajaran dari tatap muka menjadi pembelajaran daring secara tiba-tiba mengalami banyak kendala dalam pelaksanaannya. Masalah yang paling umum dihadapi adalah perangkat yang kurang memadai untuk melaksanakan pembelajaran online (Annur, 2020; Asmuni, 2020; Azubuike et al., 2020; Astini, 2020), biaya kuota internet yang mahal serta jaringan internet yang tidak stabil (Annur, 2020; Azubuike et al., 2020; Bestiantono et al., 2020; Gunawan et al., 2020; Kusuma \& Hamidah, 2020; Lapitan et al., 2021; Mohammed, 2012; Muthuprasad et al., 2021; Rachmawati et al., 2020; Sadikin \& Hamidah, 2020). Kendala lainnya adalah baik guru maupun siswa masih banyak yang belum menguasai teknologi secara baik (Annur, 2020; Asmuni, 2020; Sarkity et al., 2021; Sudrajat, 2020) sehingga pembelajaran cenderung selalu dilaksanakan dengan platform yang sama yang sederhana dalam penggunaannya (Annur, 2020; Gunawan et al., 2020). Hal ini berdampak pada bentuk pembelajaran yang cenderung dilaksanakan dengan memberikan materi atau tugas saja (Perumalla et al., 2011). Selain itu, kurangnya akses pengawasan terhadap peserta didik (Asmuni, 2020) menyebabkan sulitnya melakukan evaluasi (Yansa \& Retnawati, 2021) dan menyebabkan praktikum hanya bisa dilakukan untuk jenis praktikum yang menggunakan alatalat sederhana dan dilakukan di rumah masing-masing (Ardiansyah \& Mu'aminah, 2020; Sholikah et al., 2020).

Mahasiswa calon guru dari Program Studi Pendidikan Biologi Fakultas Keguruan dan Ilmu Pendidikan Universitas Maritim Raja Ali Haji (FKIP UMRAH) yang merupakan responden pada penelitian ini memiliki kewajiban untuk melaksanakan kegiatan praktik mengajar di Sekolah. Kegiatan ini dilaksanakan dalam rangka mengaplikasikan ilmu yang telah didapatkannya selama beberapa semester. Kegiatan ini dapat menjadi bekal dan pengalaman sebelum responden tersebut lulus dan menjadi sarjana pendidikan yang bekerja sebagai guru. Pada Tahun ajaran 2020-2021, kegiatan praktik mengajar FKIP UMRAH dilaksanakan di tengah kondisi pandemi. Hal ini menjadi suatu tantangan bagi responden untuk melaksanakan praktik mengajar secara daring karena selama beberapa semester responden telah dibekali ilmu pengajaran yang lebih cenderung dapat dilaksanakan melalui pembelajaran tatap muka. Melalui artikel ini, penulis ingin memaparkan hasil survei mengenai pengalaman Calon Guru Biologi dalam melaksanakan praktik mengajar di masa pandemi COVID-19. 


\section{METODE}

Penelitian ini merupakan penelitian survei. Penelitian ini dilaksanakan pada Desember 2020. Karena penelitian ini bertujuan untuk menggali pengalaman praktik mengajar calon guru biologi di masa Pandemi COVID-19, maka responden yang dipilih pada penelitian ini merupakan mahasiswa yang melaksanakan kegiatan praktik mengajar di masa Pandemi COVID-19. Penelitian ini melibatkan semua mahasiswa semester 7 Program Studi Pendidikan Biologi FKIP UMRAH yang berjumlah 51 Mahasiswa yang telah melaksanakan kegiatan Praktik Mengajar di sekolah dalam rangka menyelesaikan Tugas Mata Kuliah Pengenalan Lapangan Persekolahan (PLP). Pengumpulan data penelitian ini dilakukan dengan menggunakan angket untuk menggali informasi mengenai kegiatan praktik mengajar yang dilakukan oleh Calon Guru Biologi pada masa pandemi COVID-19 dengan kisi-kisi angket seperti yang ditunjukkan pada Tabel 1. Angket diberikan melalui Google form yang berisi pertanyaan tertutup serta pertanyaan terbuka guna menggali informasi kualitatif dari jawaban pertanyaan tertutup yang diberikan. Informasi yang dikumpulkan pada penelitian ini adalah informasi mengenai bentuk pembelajaran yang dilakukan, persiapan perangkat pembelajaran, platform yang digunakan dalam melaksanakan pembelajaran daring, pelaksanaan pembelajaran daring, pelaksanaan evaluasi pembelajaran daring serta kendala dan manfaat yang dirasakan responden dalam melaksanakan pembelajaran daring selama praktik mengajar di masa pandemi COVID-19.

Data yang diperoleh akan dianalisis secara kuantitatif deskriptif untuk pertanyaan tertutup serta kualitatif deskriptif untuk pertanyaan terbuka. Jawaban yang diberikan oleh responden akan disajikan dengan mengelompokkan jawaban dan menampilkan persentase responden yang memberikan respon pada setiap pertanyaan tertutup. Persentase responden pada setiap pertanyaan juga akan disertai dengan deskripsi alasan yang menyertai jawaban setiap responden yang digali melalui pertanyaan terbuka. Pertanyaan terbuka diberikan melalui angket sebagai pertanyaan lanjutan berdasarkan pilihan jawaban yang dipilih oleh responden melalui pertanyaan tertutup.

Tabel 1. Kisi-kisi Pertanyaan Angket Pengalaman Praktik Mengajar selama Masa Pandemi COVID-19

\begin{tabular}{clc}
\hline No. & Aspek Pertanyaan & No. Butir pertanyaan \\
\hline 1 & Bentuk pembelajaran di masa Pandemi COVID-19 & 1 \\
2 & Persiapan perangkat pembelajaran & 2 \\
3 & Platform online yang digunakan saat pembelajaran daring & 3,4 \\
4 & Pelaksanaan pembelajaran daring (penggunaan video & $5,6,7,8,9,10,11$ \\
& pembelajaran, pelaksanaan diskusi, pemberian tugas, dan & \\
& pelaksanaan praktikum) & $12,13,14,15,16,17,18$ \\
5 & Pelaksanaan Evaluasi dalam pembelajaran daring & 19,20 \\
6 & Kendala dalam melaksanakan pembelajaran daring & 21 \\
7 & Manfaat pembelajaran daring & \\
\hline
\end{tabular}




\section{HASIL DAN PEMBAHASAN}

\section{Hasil}

Hasil survei pengalaman praktik mengajar Mahasiswa Program Studi Pendidikan Biologi FKIP UMRAH akan dipaparkan dalam beberapa bagian sebagai berikut.

\section{Bentuk pembelajaran}

Mahasiswa Pendidikan Biologi FKIP UMRAH selaku responden penelitian ini melaksanakan praktik mengajar di beberapa sekolah. Sebanyak 23 responden mengajar di SMP/Sederajat dan 28 responden lainnya mengajar di SMA/Sederajat. Dalam pelaksanaannya, tidak semua responden melaksanakan kegiatan praktik mengajar dengan pembelajaran daring secara full. Sebanyak 7,8\% responden (4 responden) pernah melaksanakan kegiatan praktik mengajar secara tatap muka untuk beberapa pertemuan seperti yang ditunjukkan pada Gambar 1.

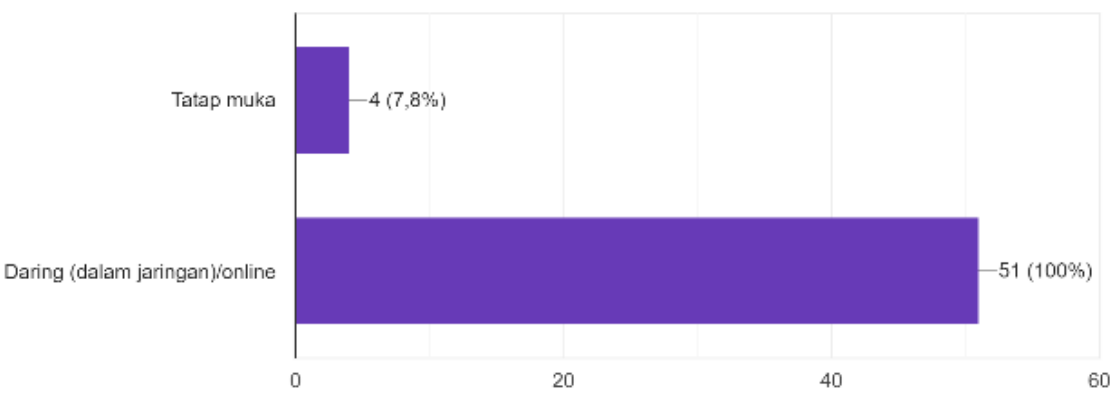

Gambar 1. Persentase Bentuk Pelaksanaan Kegiatan Praktik Mengajar di Masa Pandemi COVID-19

Responden melaksanakan kegiatan praktik mengajar dengan pembelajaran daring secara full dikarenakan tingkat penyebaran virus COVID-19 yang semakin tinggi sehingga tidak memungkinkan untuk melaksanakan kegiatan pembelajaran tatap muka. Untuk 4 responden yang melaksanakan kegiatan pembelajaran secara tatap muka, kegiatan pembelajaran dilaksanakan lebih singkat dan dengan menerapkan protokol kesehatan. Salah satu responden menyatakan bahwa kegiatan tatap muka hanya untuk keperluan pengumpulan tugas serta responden lainnya menyatakan bahwa kegiatan tatap muka dilaksanakan untuk kegiatan praktikum yang tidak memungkinkan untuk dilaksanakan secara daring.

Dalam melaksanakan pembelajaran daring, responden melaksanakan pengajaran melalui lokasi yang berbeda-beda seperti yang ditunjukkan pada Gambar 2. Sebanyak 15,38\% responden melaksanakan praktik mengajar di rumah, sebanyak $66,67 \%$ responden melaksanakan kegiatan praktik mengajar di sekolah dan 17,65\% lainnya melaksanakan kegiatan praktik mengajar dengan lokasi yang bergantian di rumah dan di sekolah. Perbedaan lokasi mengajar ini bergantung pada situasi dan kondisi pandemi COVID-19 dan juga bergantung pada kebijakan sekolah. 


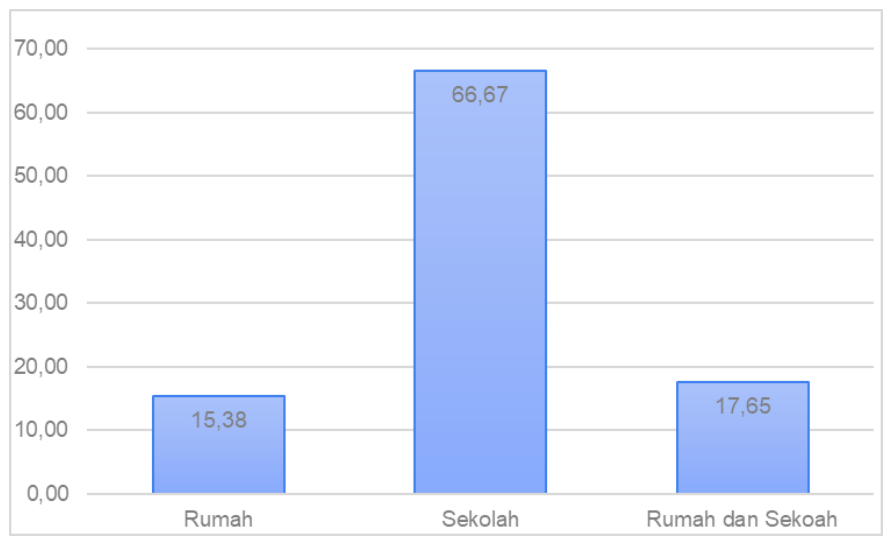

Gambar 2. Persentase Lokasi Pelaksanaan Praktik Mengajar di Masa Pandemi COVID-19

\section{Persiapan perangkat pembelajaran}

Sama seperti pembelajaran tatap muka, perangkat pembelajaran daring juga harus dipersiapkan secara baik. Dalam mempersiapkan perangkat pembelajaran daring, sebanyak 33,3 $\%$ responden menyatakan kesulitan dalam mempersiapkan perangkat pembelajaran daring sedangkan $66,7 \%$ responden lainnya menyatakan tidak mengalami kesulitan dalam mempersiapkan perangkat pembelajaran daring seperti yang ditunjukkan pada Gambar 3 .

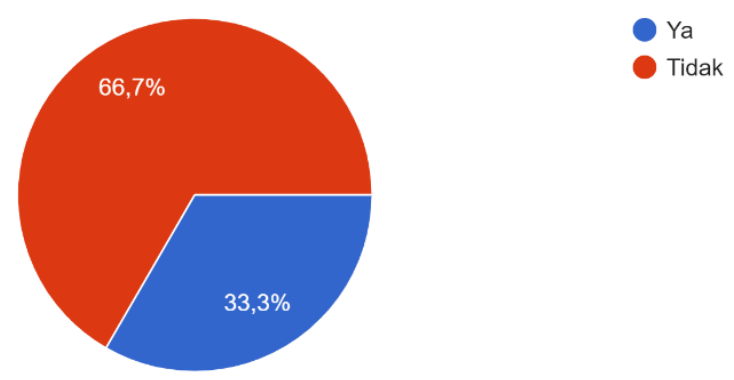

Gambar 3. Persentase Pernyataan Sulit atau Tidaknya dalam Mempersiapkan Perangkat Pembelajaran Daring

Berdasarkan alasan yang dikemukakan, kesulitan yang dialami responden dalam mempersiapkan perangkat pembelajaran daring dapat dirangkum sebagai berikut:

1) Kesulitan dalam mengalihkan perangkat pembelajaran tatap muka ke perangkat pembelajaran daring.

2) Kesulitan dalam membuat Lembar Kerja Peserta Didik (LKPD) yang dapat membangun pengetahuan siswa.

3) Kesulitan dalam menentukan metode dan strategi yang sesuai untuk pembelajaran daring.

4) Beban materi pembelajaran daring tidak sebanyak pembelajaran tatap muka sehingga sulit menentukan alokasi waktu.

Berbeda dengan responden yang mengalami kesulitan dalam mempersiapkan perangkat pembelajaran daring, responden yang menyatakan tidak mengalami kesulitan dalam membuat perangkat pembelajaran daring mengemukakan alasan yang dapat dirangkum sebagai berikut: 
1) Pembelajaran tatap muka dan pembelajaran daring hampir sama, hanya merubah bentuk pembelajaran dan metodenya saja.

2) Dalam pembuatan perangkat pembelajaran, responden diberi arahan oleh guru pamong.

3) Rencana pelaksanaan pembelajaran (RPP) dalam pembelajaran daring lebih ringkas.

\section{Platform pembelajaran daring}

Ada beberapa platform yang digunakan responden dalam melaksanakan pembelajaran daring. Kebanyakan responden menggunakan lebih dari satu platform dengan mengombinasikan kelebihan dari setiap platform. Meskipun begitu masih terdapat beberapa responden yang menggunakan satu platform saja dalam melaksanakan pembelajaran daring seperti WhatsApp, Google Classroom, atau Learning Management System (LMS). Platform yang digunakan responden dalam melaksanakan praktik mengajar dapat dilihat pada Gambar 4. Pada Gambar 4 dapat dilihat bahwa platform yang paling banyak digunakan adalah WhatsApp dan Google Classroom yang digunakan lebih dari separuh jumlah responden. Platform Zoom, Google meet, dan LMS digunakan oleh sekitar 19-30\% responden. Sebagian kecil responden juga menggunakan aplikasi lain seperti Telegram, Padlet, Cloud X, dan Schoology.

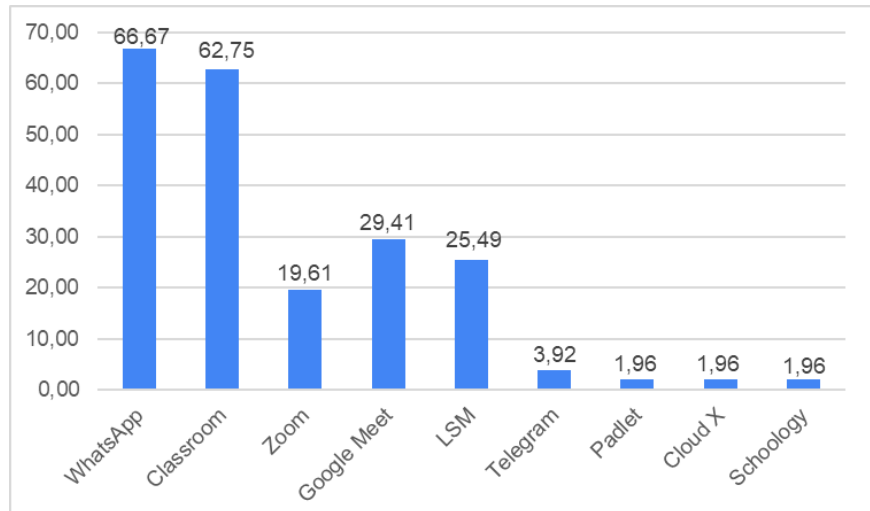

Gambar 4. Persentase Penggunaan Platform Pembelajaran Daring

Dalam melaksanakan pembelajaran daring, hanya 25 (sekitar 41\%) responden saja yang melaksanakan pembelajaran dengan menggunakan video conference. Platform video conference yang digunakan adalah Zoom, Google Meet, dan Cloud $x$ yang persentasenya dapat dilihat pada Gambar 5. Pada Gambar 5 dapat dilihat bahwa platform video conference yang paling banyak digunakan adalah Google Meet kemudian disusul oleh Zoom. Dari 25 responden tersebut terdapat 1 responden yang pernah menggunakan lebih dari satu platform video conference yaitu Zoom dan Google Meet. Adapun alasan responden menggunakan platform video conference dalam melaksanakan pembelajaran daring adalah memudahkan interaksi dengan siswa sehingga dapat memantau sejauh mana siswa memahami materi yang disampaikan. 


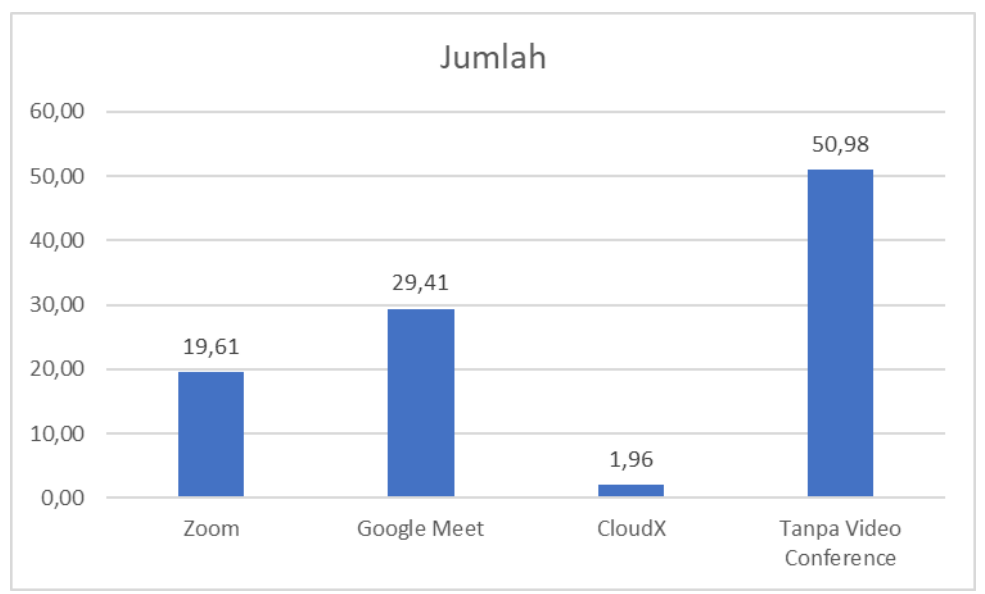

Gambar 5. Persentase Responden yang Menggunakan dan yang Tidak Menggunakan Platform Video Conference

Sebanyak 26 responden (sekitar 51\%) tidak pernah melaksanakan pembelajaran daring menggunakan platform video conference seperti yang ditunjukkan pada Gambar 5. Jawaban yang dikemukakan oleh responden juga beragam mengenai alasan mengapa responden tidak menggunakan platform video conference. Berdasarkan jawaban yang dikemukakan, kendala dalam penggunaan flattform video conference dapat dirangkum sebagai berikut:

1) Kondisi jaringan yang tidak mendukung.

2) Membutuhkan kuota internet yang banyak.

3) Kondisi smartphone atau perangkat komputer/laptop yang dimiliki siswa tidak memadai.

\section{Pelaksanaan Pembelajaran}

Ada berbagai cara yang dilakukan oleh responden dalam melaksanakan praktik mengajar. Cara yang dilakukan setiap responden berbeda-beda, ada yang menerapkan satu cara saja dan ada juga yang memvariasikan berbagai cara. Cara pelaksanaan pembelajaran daring beserta jumlah responden yang pernah menerapkannya dapat dilihat pada Tabel 2. Pada Tabel 2 dapat dilihat bahwa cara yang paling banyak diterapkan oleh responden dalam melaksanakan praktik mengajar adalah dengan membuat bahan ajar dalam bentuk PowerPoint dan membagikannya ke siswa melalui WhatsApp diikuti dengan pemberian tugas.

Tabel 2. Cara Pelaksanaan Pembelajaran Daring

\begin{tabular}{clc}
\hline No & \multicolumn{1}{c}{ Cara Pelaksanaan Pembelajaran Daring } & $\begin{array}{c}\text { Jumlah } \\
\text { responden }\end{array}$ \\
\hline 1 & $\begin{array}{l}\text { Menginstruksi siswa untuk membaca buku teks pada halaman tertentu diikuti } \\
\text { dengan pemberian tugas. }\end{array}$ & 23 \\
2 & $\begin{array}{l}\text { Membuat bahan ajar dalam Microsoft PowerPoint dan membagikannya melalui } \\
\text { WhatsApp diikuti dengan pemberian tugas. }\end{array}$ & 40 \\
3 & Membuat bahan ajar dalam Microsoft Word/PDF diikuti dengan pemberian tugas. & 22 \\
4 & Membuat LKPD dan membagikan kepada siswa sehingga siswa belajar secara & 28
\end{tabular}


mandiri di rumah.

5 Membuat video pembelajaran.

6 Memberikan tugas terkait materi yang dipelajari (tanpa memberikan bahan ajar ataupun menginstruksi siswa untuk membaca buku teks) kemudian siswa secara mandiri mencari jawaban dari tugas yang diberikan menggunakan berbagai sumber referensi yang dimiliki.

Pada Tabel 2 dapat dilihat bahwa sebanyak 29 responden pernah melaksanakan pembelajaran daring dengan membuat video pembelajaran dan membagikannya ke siswa untuk dipelajari secara mandiri. Berdasarkan alasan yang dikemukakan, tujuan pembuatan video pembelajaran adalah agar pembelajaran menjadi lebih menarik dan siswa lebih memahami materi yang diajarkan melalui media audio visual. Sebanyak 22 responden lainnya tidak pernah membuat video pembelajaran selama melaksanakan pembelajaran daring. Berdasarkan alasan yang dikemukakan, kendala dalam pembuatan video pembelajaran meliputi perangkat laptop dan handphone yang kurang mendukung, waktu yang dibutuhkan untuk membuat video pembelajaran yang cukup lama, kondisi jaringan yang tidak mendukung untuk mendownload atau mengakses video pembelajaran, serta banyaknya kuota yang dibutuhkan untuk mendownload atau mengakses video pembelajaran.

Menerapkan pembelajaran dengan sistem diskusi merupakan hal yang sulit dalam melaksanakan pembelajaran daring. Hal ini ditunjukkan oleh sedikitnya jumlah responden yang menerapkan sistem diskusi yaitu hanya 5 responden. Berdasarkan jawaban yang diberikan, responden melaksanakan diskusi dengan membagi siswa ke dalam beberapa kelompok berdasarkan lokasi tempat tinggal siswa kemudian diskusi dilaksanakan di salah satu rumah siswa dengan tetap menerapkan protokol kesehatan dan dipantau oleh orangtua siswa. Selain itu, salah seorang responden juga memanfaatkan platform Schoolgy untuk melaksanakan pembelajaran dengan sistem diskusi. Sebanyak 46 responden lainnya tidak pernah melaksanakan pembelajaran dengan sistem diskusi kelompok dengan alasan yang dapat dirangkum sebagai berikut:

1) Guru mengalami kesulitan dalam memantau aktivitas siswa.

2) Kondisi jaringan yang tidak stabil.

3) Siswa yang cenderung pasif selama pembelajaran daring.

4) Durasi pembelajaran daring yang lebih singkat daripada pembelajaran tatap muka.

Dalam memberikan tugas selama melaksanakan praktik mengajar di masa pandemi COVID-19, cara yang digunakan oleh responden juga beragam. Ada responden yang menerapkan satu cara dan ada juga yang mengombinasikan berbagai cara. Berdasarkan hasil survei, cara yang dilakukan oleh responden dalam memberikan tugas selama melaksanakan pembelajaran daring serta jumlah responden yang menerapkan setiap cara dapat dilihat pada 
Tabel 3. Pada Tabel 3 dapat dilihat bahwa platform yang paling banyak digunakan oleh responden dalam memberikan tugas ke siswa selama melaksanakan praktik mengajar adalah Google Classroom, WhatsApp, dan Google Form.

Tabel 3. Cara Responden Memberikan Tugas Selama Melaksanakan Pembelajaran Daring

\begin{tabular}{clc}
\hline No & \multicolumn{1}{c}{ Cara Pemberian Tugas } & $\begin{array}{c}\text { Jumlah } \\
\text { Responden }\end{array}$ \\
\hline 1 & Memberikan tugas melalui WhatsApp Group (WAG) lalu tugas dikumpulkan ke & 18 \\
& WA guru & Memberikan tugas melalui WAG kemudian dikumpulkan langsung ke sekolah \\
3 & memberikan tugas memalui Google Form & 2 \\
4 & memberikan tugas melalui Google Classroom & 19 \\
5 & memberikan tugas Melalui LMS & 30 \\
6 & Memberikan tugas melalui Telegram & 2 \\
7 & memberikan tugas melalui Schoology & 2 \\
\hline
\end{tabular}

Terkait pengerjaan tugas selama pembelajaran daring, terdapat tanggapan yang beragam dari siswa terhadap tugas yang diberikan. 26 responden menyatakan bahwa siswa pernah mengeluhkan tugas yang diberikannya sedangkan 25 responden lainnya menyatakan siswa tidak pernah mengeluhkan tugas yang diberikan. Berdasarkan jawaban yang diberikan, keluhan yang diberikan oleh siswa terkait tugas yang diberikan dapat dirangkum sebagai berikut:

1) Siswa tidak memahami materi terkait tugas yang diberikan.

2) Jumlah tugas yang terlalu banyak.

3) Waktu pengerjaan tugas yang terlalu singkat.

Idealnya pembelajaran biologi dilaksanakan secara praktikum di laboratorium untuk melatih siswa mengonstruksi ilmu pengetahuan melalui kerja ilmiah. Dalam praktiknya, hanya 22 responden yang melaksanakan praktikum sedangkan 29 responden lainnya tidak pernah melaksanakan praktikum. Berdasarkan jawaban yang diberikan, responden menyatakan bahwa praktikum dilaksanakan di rumah masing-masing dengan menggunakan alat dan bahan yang mudah didapatkan. Adapun cara melaksanakan praktikumnya adalah dengan memberikan petunjuk pelaksanaan praktikum secara tertulis dan ada juga yang memberikan tutorial pelaksanaan praktikum dengan menggunakan video pembelajaran yang dapat dicontoh dan diikuti oleh siswa secara langsung. Adapun kendala yang dialami oleh responden yang tidak melaksanakan praktikum selama melaksanakan pembelajaran di masa pandemi COVID-19 adalah sulitnya mengondisikan siswa untuk melaksanakan praktikum di rumah masing-masing tanpa diawasi secara langsung oleh guru serta alat dan bahan praktikum yang sulit didapatkan. 


\section{Evaluasi dalam pembelajaran daring}

Dalam melakukan evaluasi, responden mengalami kesulitan untuk mengukur kemampuan siswa. Kesulitan dalam mengukur kemampuan siswa dirasakan oleh responden tidak hanya pada aspek kognitif, tetapi juga pada aspek psikomotor dan afektif. Hal ini dapat dilihat dari jawaban siswa yang menyatakan kesulitan dalam melakukan evaluasi seperti yang ditunjukkan pada Tabel 4.

Tabel 4. Jumlah Responden yang Menyatakan Kesulitan dalam Melakukan Pengukuran

\begin{tabular}{lccc}
\hline \multicolumn{1}{c}{ Pertanyaan } & Aspek pengukuran & Jawaban & $\begin{array}{c}\text { Jumlah Responden yang } \\
\text { Memilih Jawaban }\end{array}$ \\
\hline Apakah kamu mengalami kesulitan & Kognitif & Ya & 37 \\
dalam melakukan pengukuran & & Tidak & 14 \\
terhadap aspek & Psikomotor & Ya & 38 \\
& & Tidak & 13 \\
& \multirow{2}{*}{ Afektif } & Ya & 33 \\
& & Tidak & 18 \\
\hline
\end{tabular}

Berdasarkan alasan yang dikemukakan, kesulitan dalam melakukan pengukuran terhadap aspek kognitif adalah sulitnya guru memonitor siswa saat belajar, saat mengerjakan tugas, maupun saat melaksanakan ujian sehingga sulit diketahui apakah hasil pengerjaan tugas atau ujian tersebut benar-benar dari hasil kemampuannya sendiri atau menyontek kepada teman atau sumber lainnya. Alasan yang sama juga diungkapkan saat menyatakan kesulitan dalam melakukan pengukuran terhadap aspek psikomotor dan afektif. Pembelajaran daring menyulitkan guru untuk mengetahui bagaimana kemampuan siswa, keterampilan siswa maupun sikap siswa dalam belajar maupun dalam berinteraksi dengan guru maupun dengan temantemannya.

Dalam melaksanakan evaluasi, responden menggunakan platform-platform tertentu dengan mempertimbangkan kebutuhan evaluasi dan keunggulan dari platform yang digunakan. Banyak dari responden menggunakan lebih dari satu platform dalam melaksanakan evaluasi. Meskipun begitu beberapa responden hanya menggunakan platform tunggal untuk melaksanakan evaluasi sepertinya WhatsApp, Google Form, Google Classroom atau Learning Management System (LMS). Adapun platform yang digunakan responden dalam melaksanakan evaluasi selama melaksanakan pembelajaran daring dapat dilihat pada Gambar 6. Pada Gambar 6 dapat dilihat bahwa platform yang banyak digunakan oleh responden dalam melakukan evaluasi adalah Google Form, Google Classroom, dan WhatsApp. Hal ini juga menunjukkan bahwa platform WhatsApp dan Google Classroom selain mendukung pelaksanaan pembelajaran, kedua platform tersebut juga mendukung pelaksanaan evaluasi pembelajaran. 


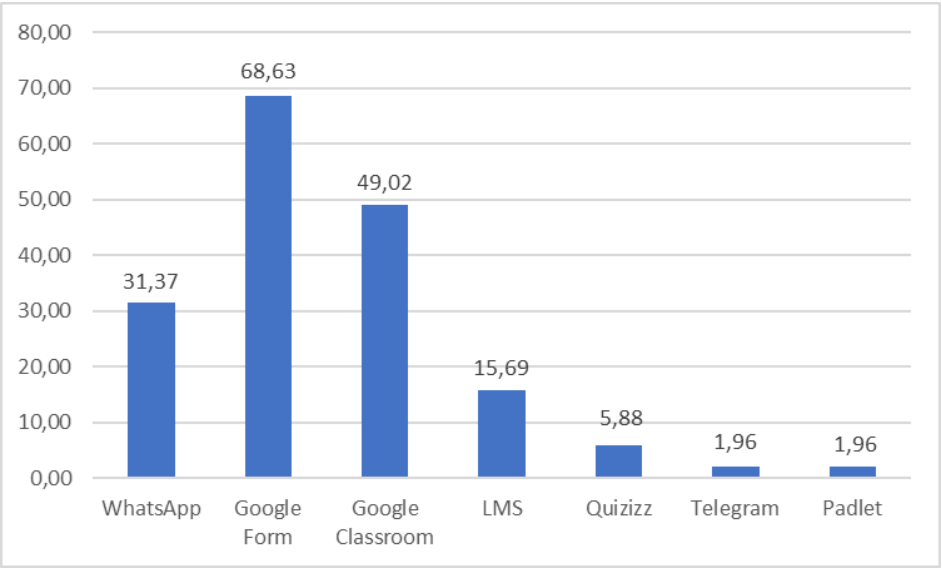

Gambar 6. Platform yang Digunakan Responden dalam Melakukan Evaluasi Pembelajaran Daring dan Persentase Responden Yang Menggunakannya

\section{Kendala pelaksanaan pembelajaran daring}

Pelaksanaan pembelajaran daring mengalami berbagai kendala, baik yang dirasakan oleh guru maupun siswa. Kendala yang dialami oleh responden selaku guru yang melaksanakan pembelajaran daring dapat dilihat pada Gambar 7. Pada Gambar 7 dapat dilihat bahwa kendala yang paling banyak dialami oleh responden yang melaksanakan praktik mengajar adalah kondisi jaringan yang tidak memadai untuk melaksanakan pembelajaran daring dan mahalnya biaya kuota internet.

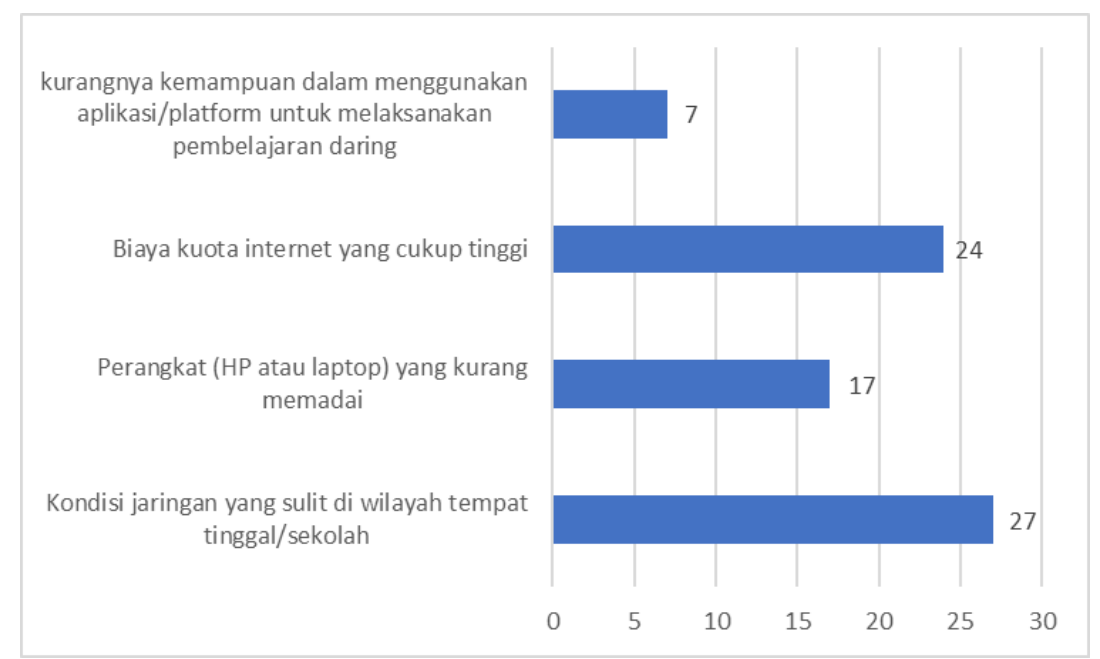

Gambar 7. Kendala yang Dialami Responden dalam Melaksanakan Pembelajaran Daring

Selain guru, siswa juga mengalami kesulitan saat dalam mengikuti pembelajaran daring. Berdasarkan jawaban dari responden, kendala yang dialami oleh peserta didiknya selama mengikuti pembelajaran daring dapat dilihat pada Gambar 8. Pada Gambar 8 dapat dilihat bahwa kendala yang paling banyak dialami oleh siswa yang dalam mengikuti kegiatan pembelajaran di masa pandemi COVID-19 adalah Perangkat seperti HP atau laptop yang kurang 
memadai untuk mengikuti pembelajaran daring disusul dengan koneksi internet yang tidak stabil dan biaya kuota internet yang mahal.

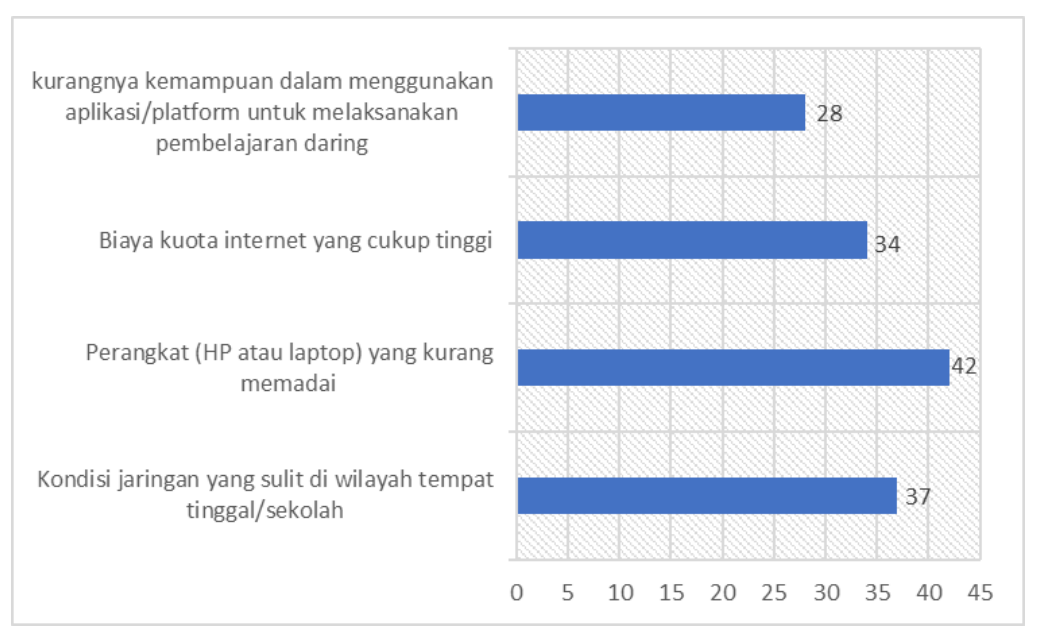

Gambar 8. Kendala yang dialami siswa dalam mengikuti pembelajaran daring

\section{Manfaat pembelajaran daring}

Meskipun terdapat banyak kendala, pelaksanaan pembelajaran daring juga memberikan banyak manfaat. Manfaat pembelajaran daring tersebut salah satunya dirasakan oleh responden yang bertindak sebagai guru yang mengajar di masa Pandemi COVID-19. Berdasarkan jawaban yang diberikan, manfaat yang dirasakan oleh responden yang merupakan mahasiswa yang melaksanakan praktik mengajar di masa Pandemi COVID-19 dapat dirangkum sebagai berikut:

1) Meningkatkan kreatifitas dalam membuat media pembelajaran berbasis IT.

2) Menambah pengetahuan dan pengalaman dalam menggunakan berbagai platform yang berguna dalam menunjang pelaksanaan pembelajaran secara online.

\section{Pembahasan}

Hasil penelitian menunjukkan bahwa pelaksanaan praktik mengajar yang dilaksanakan oleh responden dilaksanakan secara daring. Hal ini merupakan upaya pencegahan dan pengendalian penyebaran COVID-19 (Chang et al., 2020; Wang et al., 2020) yang salah satunya dengan menutup institusi pendidikan (UNESCO, 2019). Pelaksanaan pembelajaran daring juga telah sesuai dengan surat edaran kemendikbud mengenai sistem pembelajaran daring yang dilaksanakan selama pandemi COVID-19 sebagai upaya pengendalian penyebaran COVID-19 (Kemdikbud, 2020a; Kemendikbud, 2020).

Dalam pelaksanaannya, responden masih beradaptasi dalam melaksanakan pembelajaran daring sama seperti kebanyakan guru. Hal ini disebabkan karena pembelajaran daring merupakan suatu hal yang baru (Annur, 2020; Astini, 2020). Hal ini menyebabkan responden juga cenderung melaksanakan pembelajaran daring dengan hanya membagikan materi ajar dan memberikan tugas sejalan dengan hasil penelitian Perumalla et al (2011). Hal ini 
menyebabkan siswa banyak mengeluhkan tugas karena tidak memahami materi yang dipelajari dan jumlah tugas yang dianggap terlalu banyak sejalan dengan hasil penelitian Oktawirawan (2020).

Hasil penelitian menunjukkan bahwa dalam pelaksanaan pembelajaran, baik responden yang merupakan guru yang melaksanakan praktik mengajar maupun siswa yang mengikuti pembelajaran daring mengalami beberapa kendala. Hasil penelitian menunjukkan bahwa kendala yang dialami responden sama dengan kendala pembelajaran daring yang ditemukan pada beberapa penelitian yaitu perangkat pembelajaran daring yang kurang memadai (Annur, 2020; Asmuni, 2020; Azubuike et al., 2020; Astini, 2020) serta koneksi internet yang tidak stabil dan kuota internet yang mahal (Annur, 2020; Azubuike et al., 2020; Bestiantono et al., 2020; Gunawan et al., 2020; Kusuma \& Hamidah, 2020; Lapitan et al., 2021; Mohammed, 2012; Muthuprasad et al., 2021; Rachmawati et al., 2020; Sadikin \& Hamidah, 2020). Hal ini menyebabkan pelaksanaan pembelajaran daring lebih sering dilaksanakan menggunakan platform yang sederhana dalam penggunaannya (Annur, 2020; Gunawan et al., 2020). Hasil penelitian menunjukkan bahwa responden cenderung menggunakan WhatsApp dan Google Classroom yang memang praktis dan sederhana dalam penggunaannya dan hal ini sejalan dengan banyak hasil penelitian (Bacher-Hicks et al., 2021; Gunawan et al., 2020; Hindrasti \& Sabekti, 2020; Mishra et al., 2020; Ningsih, 2020; Oktawirawan, 2020; Zhafira et al., 2020). Meskipun platform video conference seperti Zoom dan Google Meet dapat memberikan hasil pembelajaran daring yang lebih efektif (Cuaca Dharma et al., 2017; Elzainy et al., 2020; Lapitan et al., 2021; Muthuprasad et al., 2021; Puspitorini, 2020; Rustaman, 2020) tapi hasil penelitian menunjukkan bahwa hanya sedikit responden yang menggunakannya dikarenakan oleh kendala-kendala tersebut. Kendalakendala ini juga menyebabkan hampir setengah dari jumlah keseluruhan responden tidak menerapkan pembelajaran asynchronous dengan membuat video pembelajaran, meskipun hasil penelitian menunjukkan pembelajaran asynchronous efektif diterapkan dalam pembelajaran daring (Kim et al., 2020; Lapitan et al., 2021; Muthuprasad et al., 2021).

Kendala lain yang dialami responden dalam melaksanakan pembelajaran daring adalah sulitnya melakukan pengawasan terhadap aktivitas belajar siswa sejalan dengan hasil penelitian Asmuni (2020). Hal ini menyebabkan responden sulit dalam melaksanakan diskusi dalam pembelajaran, melaksanakan praktikum, bahkan melaksanakan evaluasi. Sejalan dengan hasil penelitian Yansa \& Retnawati (2021), sulitnya melakukan pengawasan terhadap siswa menyebabkan sulitnya melakukan penilaian yang dapat merepresentasikan kemampuan siswa yang sebenarnya baik pada aspek pengetahuan, sikap, maupun keterampilan.

Selain menemukan berbagai kendala, responden juga mendapatkan manfaat dari praktik mengajar selama masa pandemi COVID-19. Manfaat yang paling dirasakan oleh responden adalah meningkatnya penguasaan teknologi baik dalam menggunakan platform-platform online 
maupun membuat media berbasis IT. Hal ini sejalan dengan hasil penelitian Elzainy et al., (2020) dan Astini (2020) yang menemukan adanya percepatan penguasaan teknologi melalui pembelajaran online.

\section{SIMPULAN}

Berdasarkan hasil penelitian dapat disimpulkan bahwa praktik mengajar di masa pandemi COVID-19 yang dilaksanakan oleh Mahasiswa Pendidikan Biologi FKIP UMRAH masih mengalami berbagai kendala. Responden yang masih beradaptasi dengan sistem pembelajaran daring sehingga responden cenderung melaksanakan pembelajaran daring dengan hanya membagikan materi ajar dan memberikan tugas kepada siswa. Permasalahan yang dialami responden selaku guru dan siswa yang diajarnya dalam melaksanakan pembelajaran daring adalah perangkat yang kurang memadai, koneksi internet yang tidak stabil dan kuota internet yang mahal. Permasalahan tersebut menyebabkan sulitnya melaksanakan berbagai bentuk pembelajaran seperti diskusi dan praktikum serta menyebabkan sulitnya pelaksanaan pembelajaran dengan menggunakan platform video conference maupun pelaksanaan pembelajaran asynchronous dengan membuat video pembelajaran. Kendala terkait koneksi internet, kuota, dan perangkat yang kurang memadai menyebabkan pembelajaran daring lebih banyak dilaksanakan menggunakan platform yang praktis dan sederhana dalam penggunaannya seperti WhatsApp dan Google Classroom. Kendala lain yang dialami responden yaitu sulitnya melakukan pengawasan terhadap siswa sehingga menyulitkan responden selaku guru dalam melakukan penilaian baik dari aspek pengetahuan (kognitif), sikap (afektif), maupun keterampilan (psikomotor). Meskipun menemui berbagai kendala, pembelajaran daring juga memberikan manfaat bagi responden dalam hal peningkatan penguasaan teknologi.

Berdasarkan temuan penelitian ini, maka penulis memberikan saran untuk penelitian berikutnya dalam hal pengembangan metode pembelajaran yang efektif diterapkan dalam pembelajaran daring. Metode yang dikembangkan adalah metode yang mudah diikuti oleh siswa dan efektif serta efisien diterapkan melalui penggunaan platform-platform online. Metode pembelajaran yang dikembangkan juga diharapkan dapat memberikan ruang seluas-luasnya kepada siswa untuk aktif dalam mengonstruksi ilmu pengetahuan secara mandiri dengan guru hanya sebagai fasilitator meskipun pembelajaran dilakukan secara daring dimana guru dan siswa tidak berada pada lokasi yang sama saat pembelajaran berlangsung.

\section{REFERENSI}

Andel, S. A., de Vreede, T., Spector, P. E., Padmanabhan, B., Singh, V. K., \& Vreede, G. J. de. (2020). Do social features help in video-centric online learning platforms? A social presence perspective. Computers in Human Behavior, 113(July), 106505. https://doi.org/10.1016/j.chb.2020.106505

Annur, M. F. (2020). Analisis Kesulitan Mahasiswa Pendidikan Matematika Dalam 
Pembelajaran Daring Pada Masa Pandemi COVID-19. Jurnal Kajian, Penelitian Dan Pengembangan Kependidikan, 11, 195-201.

Ardiansyah, \& Mu'aminah. (2020). Analisis Sikap Ilmiah Peserta Didik Pada Praktikum Mandiri Berbasis Proyek Pada Materi Optik SMPN 4 Sojol di Masa Pandemik. 1(2).

Asmuni, A. (2020). Problematika Pembelajaran Daring di Masa Pandemi COVID-19 dan Solusi Pemecahannya. Jurnal Paedagogy, 7(4), 281. https://doi.org/10.33394/jp.v7i4.2941

Astini, N. K. S. (2020). Tantangan Dan Peluang Pemanfaatan Teknologi Informasi Dalam Pembelajaran Online Masa COVID-19. Cetta: Jurnal Ilmu Pendidikan, 3(2), 241-255. https://doi.org/10.37329/cetta.v3i2.452

Azubuike, O. B., Adegboye, O., \& Quadri, H. (2020). Who gets to learn in a pandemic? Exploring the digital divide in remote learning during the COVID-19 pandemic in Nigeria. International Journal of Educational Research Open, December, 100022. https://doi.org/10.1016/j.ijedro.2020.100022

Bacher-Hicks, A., Goodman, J., \& Mulhern, C. (2021). Inequality in household adaptation to schooling shocks: Covid-induced online learning engagement in real time. Journal of Public Economics, 193, 104345. https://doi.org/10.1016/j.jpubeco.2020.104345

Bestiantono, D. S., Agustina, P. Z. R., \& Cheng, T.-H. (2020). How Students' Perspectives about Online Learning Amid the COVID-19 Pandemic? Studies in Learning and Teaching, 1(3), 133-139. https://doi.org/10.46627/silet.v1i3.46

Bulan, S., \& Zainiyati, H. S. (2020). Pembelajaran Online Berbasis Media Google Formulir dalam Tanggap Work From Home Masa Pandemi COVID-19 di Madrasah Ibtidaiyah Negeri (MIN) 1 Paser. SYAMIL: Jurnal Pendidikan Agama Islam (Journal of Islamic Education), 8(1), 15-34. https://doi.org/10.21093/sy.v8i1.2300

Cahyani, A., Listiana, I. D., \& Larasati, S. P. D. (2020). Motivasi Belajar Siswa SMA pada Pembelajaran Daring di Masa Pandemi COVID-19. IQ (Ilmu Al-Qur'an): Jurnal Pendidikan Islam, 3(01), 123-140. https://doi.org/10.37542/iq.v3i01.57

Chang, R., Wang, H., Zhang, S., Wang, Z., Dong, Y., Tsamlag, L., Yu, X., Xu, C., Yu, Y., Long, R., Liu, N. N., Chu, Q., Wang, Y., Xu, G., Shen, T., Wang, S., Deng, X., Huang, J., Zhang, X., ... Cai, Y. (2020). Phase- and epidemic region-adjusted estimation of the number of coronavirus disease 2019 cases in China. Frontiers of Medicine, 14(2), 199-209. https://doi.org/10.1007/s11684-020-0768-7

Cuaca Dharma, H. R., Asmarani, D., \& Dewi, U. P. (2017). Basic Japanese Grammar and Conversation e-learning through Skype and Zoom Online Application. Procedia Computer Science, 116, 267-273. https://doi.org/10.1016/j.procs.2017.10.055

Cucinotta, D., \& Vanelli, M. (2020). WHO declares COVID-19 a pandemic. Acta Biomedica, 91(1), 157-160. https://doi.org/10.23750/abm.v91i1.9397

Dahalan, N., Hassan, H., \& Atan, H. (2012). Student Engagement in Online Learning : Learners Attitude Toward E-Mentoring. Procedia - Social and Behavioral Sciences, 67(November 2011), 464-475. https://doi.org/10.1016/j.sbspro.2012.11.351

Elzainy, A., El Sadik, A., \& Al Abdulmonem, W. (2020). Experience of e-learning and online assessment during the COVID-19 pandemic at the College of Medicine, Qassim University. Journal of Taibah University Medical Sciences, 15(6), 456-462. https://doi.org/10.1016/j.jtumed.2020.09.005

Fernando, W. (2018). Show me your true colours: Scaffolding formative academic literacy assessment through an online learning platform. Assessing Writing, 36(March), 63-76. https://doi.org/10.1016/j.asw.2018.03.005

Glava, C. C., \& Glava, A. E. (2012). Time Management on the On-Line Learning Platforms. A Case Study Regarding the BSCW Platform Used by Future Teacher Student. Procedia Social and Behavioral Sciences, 46, 3551-3555. https://doi.org/10.1016/j.sbspro.2012.06.103

Gunawan, Suranti, N. M. Y., \& Fathoroni. (2020). Variations of models and learning platforms for prospective teachers during the COVID-19 pandemic period. Indonesian Journal of Teacher Education, 1(2), 61-70.

Hanifah Salsabila, U., Irna Sari, L., Haibati Lathif, K., Puji Lestari, A., \& Ayuning, A. (2020). Peran Teknologi Dalam Pembelajaran Di Masa Pandemi COVID-19. Al-Mutharahah: Jurnal 
Penelitian Dan Kajian Sosial Keagamaan, 17(2), 188-198. https://doi.org/10.46781/almutharahah.v17i2.138

Hindrasti, N. E. K., \& Sabekti, A. W. (2020). Pengalaman Calon Guru Sains Dalam Pembelajaran Daring Selama Masa Pandemi COVID-19. Jurnal Pendidikan Sains (Jps), 8(2), 139. https://doi.org/10.26714/jps.8.2.2020.139-152

Ishtaiwa, F. F., \& Aburezeq, I. M. (2015). The impact of Google Docs on student collaboration: A UAE case study. Learning, Culture and Social Interaction, 7, 85-96. https://doi.org/10.1016/j.1csi.2015.07.004

Kemdikbud. (2020a). Edaran Tentang Pencegahan Wabah COVID-19 di Lingkungan Satuan Pendidikan Seluruh Indonesia. 1-3. http://www.kemdikbud.go.id

Kemdikbud. (2020b). Surat Edaran Menteri Pendidikan dan Kebudayaan Republik Indonesia Nomor 35952/MPK.A/HK/2020. Mendikbud RI, 1-2. https://www.kemdikbud.go.id

Kemendikbud. (2020). Pedoman Pelaksanaan Belajar Dari Rumah Selama Darurat Bencana COVID-19 di Indonesia. Kementerian Pendidkan Dan Kebudayaan, 15. https://www.kemdikbud.go.id/main/files/download/5b9eda821425005

Kim, D., Lee, Y., Leite, W. L., \& Huggins-Manley, A. C. (2020). Exploring student and teacher usage patterns associated with student attrition in an open educational resource-supported online learning platform. Computers and Education, 156, 103961. https://doi.org/10.1016/j.compedu.2020.103961

Kusuma, J. W., \& Hamidah, H. (2020). Perbandingan Hasil Belajar Matematika Dengan Penggunaan Platform Whatsapp Group Dan Webinar Zoom Dalam Pembelajaran Jarak Jauh Pada Masa Pandemik Covid 19. JIPMat, 5(1). https://doi.org/10.26877/jipmat.v5i1.5942

Lapitan, L. D., Tiangco, C. E., Sumalinog, D. A. G., Sabarillo, N. S., \& Diaz, J. M. (2021). An Effective Blended Online Teaching and Learning Strategy during the COVID-19 Pandemic. Education for Chemical Engineers, 35(May 2020), 116-131. https://doi.org/10.1016/j.ece.2021.01.012

Lloyd-Sherlock, P. G., Kalache, A., McKee, M., Derbyshire, J., Geffen, L., Casas, F. G. O., \& Gutierrez, L. M. (2020). WHO must prioritise the needs of older people in its response to $\begin{array}{llll}\text { the COVID-19 pandemic. The } & \text { BMJ, 368(March), } 2020 .\end{array}$ https://doi.org/10.1136/bmj.m1164

Mahase, E. (2020). COVID-19: WHO declares pandemic because of "alarming levels" of spread, severity, and inaction. BMJ (Clinical Research Ed.), 368(March), m1036. https://doi.org/10.1136/bmj.m1036

Meulenbroeks, R. (2020). Suddenly fully online: A case study of a blended university course moving online during the COVID-19 pandemic. Heliyon, 6(12), e05728. https://doi.org/10.1016/j.heliyon.2020.e05728

Mishra, L., Gupta, T., \& Shree, A. (2020). International Journal of Educational Research Open Online teaching-learning in higher education during lockdown period of COVID-19 pandemic. International Journal of Educational Research Open, 1(September), 100012. https://doi.org/10.1016/j.ijedro.2020.100012

Mohammed, A. H. (2012). Empowering the Online Education for Rural Community through Correlated Content Development. Procedia - Social and Behavioral Sciences, 67(November), 16-25. https://doi.org/10.1016/j.sbspro.2012.11.303

Muthuprasad, T., Aiswarya, S., Aditya, K. S., \& Jha, G. K. (2021). Students' perception and preference for online education in India during COVID -19 pandemic. Social Sciences \& Humanities Open, 3(1), 100101. https://doi.org/10.1016/j.ssaho.2020.100101

Napitupulu, R. M. (2020). Dampak pandemi COVID-19 terhadap kepuasan pembelajaran jarak

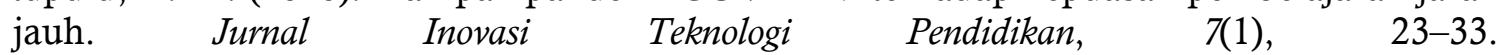
https://doi.org/10.21831/jitp.v7i1.32771

Ningsih, S. (2020). Persepsi Mahasiswa Terhadap Pembelajaran Daring Pada Masa Pandemi COVID-19. JINOTEP (Jurnal Inovasi Dan Teknologi Pembelajaran): Kajian Dan Riset Dalam Teknologi Pembelajaran, 7(2), 124-132. https://doi.org/10.17977/um031v7i22020p124

Oktawirawan, D. H. (2020). Faktor Pemicu Kecemasan Siswa dalam Melakukan Pembelajaran 
Daring di Masa Pandemi COVID-19. Jurnal Ilmiah Universitas Batanghari Jambi, 20(2), 541. https://doi.org/10.33087/jiubj.v20i2.932

Perumalla, C., Mak, J., Kee, N., \& Matthews, S. (2011). Procedia Computer Integrating web applications to provide an effective distance online learning environment for students. Procedia Computer Science, 3, 770-784. https://doi.org/10.1016/j.procs.2010.12.127

Phan, T. (2020). Novel coronavirus: From discovery to clinical diagnostics. Infection, Genetics and Evolution, 79(January), 104211. https://doi.org/10.1016/j.meegid.2020.104211

Puspitorini, F. (2020). Strategi Pembelajaran Di Perguruan Tinggi Pada Masa Pandemi COVID19. Jurnal Kajian Ilmiah, 1(1), 99-106. https:// doi.org/10.31599/jki.v1i1.274

Rachmawati, Y., Ma'arif, M., Fadhillah, N., Inayah, N., Ummah, K., Siregar, M. N. F., Amalyaningsih, R., C., F. A. A., \& F., A. A. (2020). Studi Eksplorasi Pembelajaran Pendidikan IPA Saat Masa Pandemi COVID-19 di UIN Sunan Ampel Surabaya. Indonesian Journal of Science Learning, Volume 1,(1), 32-36. http://jurnalftk.uinsby.ac.id/index.php/IJSL/article/view/633

Rahiem, M. D. H. (2021). Remaining motivated despite the limitations: University students' learning propensity during the COVID-19 pandemic. Children and Youth Services Review, 120(December 2020), 105802. https://doi.org/10.1016/j.childyouth.2020.105802

Rustaman, A. H. (2020). Efektivitas Penggunaan Aplikasi Daring, Video Conference Dan Sosial Media Pada Mata Kuliah Komputer Grafis 1 Di Masa Pandemi COVID-19. Jurnal Ilmu Sosial Dan Pendidikan, 4(3), 557-562.

Sadikin, A., \& Hamidah, A. (2020). Research Article Pembelajaran Daring di Tengah Wabah COVID-19. BIODIK: Jurnal Ilmiah Pendidikan Biologi, 6(2), 214-224. https://doi.org/10.22437/bio.v6i2.9759

Sarkity, D., Putri, A. N., \& Fernando, A. (2021). Profil Pemanfaatan Video Pembelajaran Sebagai Media Pembelajaran Pada Masa Pandemi COVID-19 di SMAN 1 Bintan Timur. 6(6), 380-390. https://doi.org/https://doi.org/10.29303/jipp.v6i3.231

Shereen, M. A., Khan, S., Kazmi, A., Bashir, N., \& Siddique, R. (2020). COVID-19 infection: Origin, transmission, and characteristics of human coronaviruses. Journal of Advanced Research, 24, 91-98. https://doi.org/10.1016/j.jare.2020.03.005

Sholikah, T., Mardhotillah, A. F., Indriyani, L. A., Wulandari, V. A., Sari Kuraesin, P. P., Abadiya Al-Khotim, N. L. S., Irjiananto, M. Y., Fatmah, Ma'arif, M., Fadhillah, N., \& Rachmawati, Y. (2020). Studi Eksplorasi Kegiatan Praktikum Sains Saat Pandemi COVID19 Ta'imul. Indonesian Journal of Science, 1(2), 67-75. http://jurnalftk.uinsby.ac.id/index.php/IJSL

Sohrabi, C., Alsafi, Z., Neill, N. O., Khan, M., Kerwan, A., Al-Jabir, A., Iosifidis, C., \& Agha, R. (2020). World Health Organization declares global emergency: A review of the 2019 novel coronavirus (COVID-19). 76(January).

Sudrajat, J. (2020). Kompetensi Guru Di Masa Pandemi COVID-19. Jurnal Riset Ekonomi Dan Bisnis, 13(1), 100-110. http://journals.usm.ac.id/index.php/jreb

Sun, J. C. Y. (2014). Influence of polling technologies on student engagement: An analysis of student motivation, academic performance, and brainwave data. Computers and Education, 72, 80-89. https://doi.org/10.1016/j.compedu.2013.10.010

UNESCO. (2019). Education: From Distruption to Recovery. https://en.unesco.org/covid19/educationresponse

Wang, H., Wang, Z., Dong, Y., Chang, R., Xu, C., Yu, X., Zhang, S., Tsamlag, L., Shang, M., Huang, J., Wang, Y., Xu, G., Shen, T., Zhang, X., \& Cai, Y. (2020). Phase-adjusted estimation of the number of Coronavirus Disease 2019 cases in Wuhan, China. Cell Discovery, 6(1), 4-11. https://doi.org/10.1038/s41421-020-0148-0

Yansa, H., \& Retnawati, H. (2021). Identifikasi Praktik dan Hambatan Guru dalam Asesmen Kognitif Matematika di Masa Pandemi COVID-19. Jurnal Elemen, 7(1), 84-97. https://doi.org/10.29408/jel.v7i1.2585

Zhafira, N. H., Ertika, Y., \& Chairiyaton. (2020). Persepsi Mahasiswa Terhadap Perkuliahan Daring Sebagai Sarana Pembelajaran Selama Masa Karantina COVID-19. Jurnal Bisnis Dan Kajian Strategi Manajemen, 4, 37-45. 
Zhu, N., Zhang, D., Wang, W., Li, X., Yang, B., Song, J., Zhao, X., Huang, B., Shi, W., Lu, R., Niu, P., Zhan, F., Ma, X., Wang, D., Xu, W., Wu, G., Gao, G. F., \& Tan, W. (2020). A Novel Coronavirus from Patients with Pneumonia in China, 2019. New England Journal of Medicine, 382(8), 727-733. https://doi.org/10.1056/nejmoa2001017 